\title{
Cultural, Morphological and Pathogenic Variability of Exserohilum turcicum causing Turcicum Leaf Blight in Maize
}

\author{
Geeta $^{1 *}$, D.S. Aswathanarayana ${ }^{1}$, M.K. Naik ${ }^{2}$, Mallikarjun Kenganal ${ }^{1}$ \\ and Prakash H. Kuchanur ${ }^{3}$
}
${ }^{1}$ Department of Plant Pathology, College of Agriculture, University of Agricultural Sciences, Raichur-584104, India
${ }^{2}$ Department of Plant Pathology, University of Agricultural and Horticultural Sciences, Shivamogga, India
${ }^{3}$ Department of Genetics and Plant Breeding, College of Agriculture, Bheemarayanagudi, India
*Corresponding author

\section{A B S T R A C T}

\section{Keywords}

Maize, Exserohilum turcicum, Cultural variability,

Morphological variability

Article Info

Accepted:

04 October 2019

Available Online:

10 November 2019
Turcicum leaf blight of maize caused by Exserohilum turcicum is an economically important foliar disease, the findings of the study reveals that, among the 32 isolates, tested for mycelia growth on PDA, Aedigudda (Et12), Dibbadahalli (Et14), Hulihyder (Et19), Kanakagiri (Et28) and Raichur (Et32) isolate showed an excellent mean radial growth $(90.00 \mathrm{~mm})$ and least mean radial growth was obtained in Et9 (Choornoor) isolate with mycelia growth of $69.00 \mathrm{~mm}$. Maximum number of E. turcicum isolates were having the septa of 3-8 and 3-9 with protruding hilum. Interestingly an isolate Et16 and Et28 from Hadagali and Kanakagiri respectively having 3-15 septa. Maximum size of conidia was observed in Et16 of Hadagali $(120.78 \mu \mathrm{m} \times 29.15 \mu \mathrm{m})$ followed by Et28 of Kanakagiri $(116.62 \mu \mathrm{m} \times 24.99 \mu \mathrm{m})$. In pathogen variability studies, CM-202 and MI-39 inbred lines showed significantly higher mean lesion sizes of $1.31 \mathrm{~cm}^{2}$ and $1.29 \mathrm{~cm}^{2}$ for most of the isolates respectively. Smaller lesion size of $0.26 \mathrm{~cm}^{2}$ was recorded in HS-2. Across the maize inbred lines E. turcicum, isolates from Farathabad, Bheemarayanagudi and Mataladinni produced higher mean lesion size of $1.10,1.00$ and $1.00 \mathrm{~cm}^{2}$ respectively, where as small lesion size was noticed in Kushtagi $\left(0.24 \mathrm{~cm}^{2}\right)$ and Kottur $\left(0.25 \mathrm{~cm}^{2}\right)$ isolates. CM-202 and MI-39 inbred lines showed susceptible to highly susceptible reaction to majority of the isolates (3 to 5 reaction). The inbred lines 9202B, 9208B showed highly resistant to moderately resistant reaction (1-3) whereas CI-4 and HS-2 showed highly resistant to resistant reaction. 


\section{Introduction}

Maize (Zea mays L.) is an important coarse cereal and is the third major crop in India after rice and wheat. Maize is native of Mexico and Central America by origin (Pursglove, 1972; Galaniant, 1976 and Dowswell et al., 1996) Norman E. Borlaug believed that maize has the highest yield potential among cereals. In the last two decades there was a revolution in rice and wheat and probably the next few decades will be known as era of maize (Anon., 2010). In India, it is grown over an area of 8.69 mha with a total production of about $21.81 \mathrm{mt}$ in major maize growing states like Karnataka, Andhra Pradesh, Maharashtra, Uttar Pradesh, Bihar, Rajasthan, Madhya Pradesh and Punjab together contribute 60 per cent of area and 70 per cent of maize production in India. The average maize yield in India is $25.09 \mathrm{q} / \mathrm{ha}$, which is much lower than most of the maize growing countries of the world (Anon., 2016).

About 61 diseases have been reported in India which affects the maize crop (Payak and Sharma, 1985). Based on the research efforts for the last few years under the All India Coordinated Maize Improvement Project, 16 out of 61 diseases adversely affecting this crop have been identified as major diseases. With the introduction of high yielding hybrids both indigenous, exotic and as well as use of fertilizers, there has been a tremendous increase in the area and production. But at the same time, it is prone to several foliar and stalk rots, downy mildews and ear rots (Payak et al., 1973 and Payak and Sharma, 1985). Foliar diseases of maize are arguably the primary biotic constraints to maize yields worldwide and the prevalence of these foliar diseases varies depending on the region or season (Smith, 1999).

Among the foliar diseases of maize, the turcicum leaf blight (TLB) also called as
Northern corn leaf blight caused by Exserohilum turcicum (Pass) Leonard and Suggs. (syn. Helminthosporium turcicum Pass.) is having worldwide importance. Turcicum leaf blight is one of the most important foliar fungal diseases affecting photosynthesis with severe reduction in grain yield of more than 50 per cent (Raymundo and Hooker, 1981 and Perkins and Pederson, 1987). In the present study, focus was made towards.

\section{Materials and Methods}

\section{Collection of diseased samples}

The maize plants severly infected by $E$. turcicum showing typical symptoms of turcicum leaf blight necrotic lesions were collected from parts of Raichur, Koppal, Ballari, Yadgiri and Kalaburgi districts of North Eastern Karnataka during the survey programme. The fungus $E$. turcicum was isolated by standard tissue isolation procedure and also by hyphal tip isolation procedure and later nucleus culture was maintained on potato dextrose agar slants and kept it in a refrigerator at $4{ }^{\circ} \mathrm{C}$ for all laboratory as well as other studies.

\section{Isolation of the pathogen}

The standard tissue isolation procedure was followed to isolate the pathogen. The infected leaf bits were surface sterilized in 0.01 per cent with mercuric chloride solution for 30 seconds and repeatedly washed separately in sterilized distilled water to remove the traces of mercuric chloride. Then such bits were aseptically transferred to sterilized Petri plates (1 to 2 infected bits per Petri dish) containing potato dextrose agar (PDA) in aseptic condition under laminar hood. The Petri plates were incubated at room temperature $\left(27 \pm 1{ }^{\circ} \mathrm{C}\right)$ for 15 days for fungal growth. The pure colonies developed from the bits were 
transferred to PDA slants and incubated at room temperature for 15 days. Abundant sporulation was observed after 15 days of incubation. The pathogen was purified following hyphal tip isolation technique as described below.

\section{Hyphal tip isolation and maintenance of culture}

This method was followed for maintaining of pure culture, hyphal tip isolation was done on water agar plates. Spore suspension of the pathogen was prepared in sterilized distilled water containing eight to ten spores per $\mathrm{ml}$ from 15 days old culture. One $\mathrm{ml}$ of such suspension was spread uniformly on two per cent solidified water agar plates and observed for spores under the microscope.

Single spore was marked with a marker on back side of the Petri plate and it was allowed to germinate. Such plates were periodically observed for spore germination under microscope. The hyphae growing from each cell of the single spore was traced and marked with marker. The growing tip of the hyphae was cut carefully by cork borer and transferred to PDA plates and incubated at $27 \pm 1^{0} \mathrm{C}$ for 10 days. Saltation or sectoring was also observed in the culture plates. Further the fungus was sub-cultured on PDA slants and kept in laboratory at $27 \pm 1{ }^{\circ} \mathrm{C}$ for 15 days. Such mother culture slants were preserved at 4 ${ }^{0} \mathrm{C}$ in refrigerator. Further, these cultures were sub-cultured once in a month and used for further studies.

\section{Identification of the fungus}

In order to confirm the identity of the fungu, the conidia and condiophores were observed under the high power (40X) microscope from the infected leaves of maize plant. Observations such as length, breadth and number of septa were recorded using image capturing microscope or ocular micrometer and were compared with original description of the fungus.

\section{Variability of E. turcicum}

Turcicum leaf blight infected leaf samples were collected from five districts of North Eastern Karnataka at the time of survey during kharif 2016 and pure culture of 32 isolates were maintained on PDA and later cultural and morphological studies were carried out in the laboratory.

\section{Cultural variability}

Based on the results of previous workers of Nataraj, (2014) and Rashmi, (2015) who reported that, among the different media tested PDA was found to be effective for growth and development of E. turcicum. Hence this media was selected to study the variability of cultural and morphological characteristics of pathogen.

The potato dextrose agar medium was prepared and $20 \mathrm{ml}$ of medium was poured in to the Petri plates for solidification. Five $\mathrm{mm}$ discs of different isolates of E. turcicum were placed at the centre of the each plate. These plates were incubated at $27 \pm 1{ }^{0} \mathrm{C}$ for 10 days. The variation in cultural characteristics of $E$. turcicum was investigated by selecting isolates of fungus. The cultural characteristics such as colony diameter, colony colour and pigmentation were recorded.

\section{Morphological variability}

Pure culture of 32 isolates of E. turcicum was selected for morphological variations such as shape, size of conidia and number of septa. The size of conidia was also measured using stage and ocular micrometer under compound microscope. The colonies were characterized for phenotype growth pattern and different morphotypes, shape (irregular and regular); 
growing pattern (circular and feathery); texture (velvety and cottony) were observed under in vitro. Similarly, colour was differentiated into black and grayish black. The sporulation was graded as $++++(>20$ spores/microscopic field), +++ (15-20 spores/microscopic filed), $++\quad(10-15$ spores/microscopic field $)$ and $+\quad(<10$ spores/microscopic field).

\section{Pathogen variability on maize inbred lines}

Based on morphological and cultural studies, the isolates of E. turcicum exhibiting distinct characteristics were mass multiplied on sterilized sorghum grains for 15 to 20 days. Later the sorghum grains containing the pathogen $1 \times 10^{6}$ conidia/g was placed in leaf whorls of 25 days old maize seedlings raised in pots as per the procedure of Harlapur (2005) and Khedekar (2009). The pathogen was inoculated to the maize inbred lines having varied degree of resistance to TLB. Water was sprayed to the inoculated seedlings to create humidity.

The variability of pathogen isolates was observed for time taken for lesion development, size of the lesions and extent of severity was recorded on maize seedlings using 0-5 scale. Based on the reaction the isolates of the pathogen were grouped in to highly virulent, virulent, moderatly virulent and poor virulent across the maize lines with varied degree of resistance.

\section{Results and Discussion}

\section{Variability of E. turcicum}

The host plant resistance depends on the effectiveness of resistance in plants against all the virulence races of the pathogen present in the region. Thus, studies on variability of E. turcicum have a greater significance in breeding for resistance against TLB.
The 32 isolates of E. turcicum were studied for cultural, morphological and pathogenic behaviour on differential hosts under identical conditions and the results thus obtained are discussed hereunder. All the isolates under study showed differences in growth and colony characters.

\section{Cultural characteristics}

Every living being requires food for growth and reproduction, fungi are not an exception to it. In order to culture fungi in the laboratory, it is necessary to supplement the medium with those essential nutrients for their growth and other metabolic processes. The PDA medium was selected as best source of nutrients to support the growth of fungus and it was used to study the cultural and morphological variability among the isolates.

The results showed that, maximum radial growth was observed in the isolate collected from Aedigudda (Et12), Dibbadahalli (Et14), Hulihyder (Et19), Kanakagiri (Et28) and Raichur (Et32) with colony diameter of 90.00 $\mathrm{mm}$ followed by Tuppargadde (Et27) (89.00 $\mathrm{mm}$ ), Banapur (Et7), Kottur (Et13), Hadagali (Et16), Kushtagi (Et22) and Mataladinni (Et24) with diameter of $88.00 \mathrm{~mm}$. Minimum colony diameter of $69.00 \mathrm{~mm}$ was with Choornoor (Et9) isolate. Colony growth of eightteen isolates viz., Et4, Et5, Et7, Et8, Et12, Et13, Et14, Et16, Et17, Et19, Et21, Et22, Et24, Et25, Et27, Et28, Et29 and Et32 were excellent and fast growing while poor growth was observed in Farathabad (Et2) and Choornoor (Et9) isolates (Fig. 1 and Table 1).

The grayish pigmenatation of mycelium was observed in Sidargadda (Et6), Hulihyder (Et19) and Mataladinni (Et24). Majority of the isolates showed grayish black pigmentation of mycelium and also blackish pigmentation. Whereas whitish gray coloured mycelium was observed in very few isolates collected from 
Raddewadgi (Et1), Farathabad (Et2) and Gudekote (Et11). The dark grayish coloured mycelium was observed in Tuppargadde (Et27) and dark blackish pigmentation was found in Kottur (Et13) isolates. Excellent sporulation of E. turcicum was exhibited by Hagari (Et4), Gudekote (Et11) and Kottur (Et13), Rajooru (Et23), Mataladinni (Et24), Nittali (Et26) and Tuppargadde (Et27) isolates, While Poor sporulation was noticed in majority of the isolates of Et3, Et6, Et9, Et14, Et18, Et19, Et20, Et25, Et30, and Et31.

Similar variability results were obtained by Harlapur et al., (2007) who studied on 16 isolates of E. turcicum for colony diameter, mycelia dry weight etc. The results are in accordance with the several workers (Muiru et al., 2008; Khedekar, 2009, Hulagappa, 2012, Nataraj, 2014 and Rashmi, 2015) who observed diversity in cultural characteristics such as growth rate, type of growth, colony colour and sporulation among different isolates of E. turcicum studied.

\section{Morphological variation in different isolates of $E$. turcicum}

All the isolates under the study exhibited differences in the morphological characters. The variation in morphological characters of different isolates indicated that, conidia of maximum number of isolates were having the septa of 3 to 8 and 3 to 9 with protruding hilum with spindle shaped conidia having varied number of septa.

Interestingly, an isolate Et16 and Et28 from Hadagali and Kanakagiri respectively having 3 to 15 septa, followed by 3-10 septa in Tupparagadde (Et27) isolate. Maximum size of conidia was observed in Et16 of Hadagali $(120.78 \mu \mathrm{m} \times 29.15 \mu \mathrm{m})$ followed by Et 28 of Kanakagiri $(116.62 \mu \mathrm{m} \times 24.99 \mu \mathrm{m})$ and Raichur (Et32) $(108.29 \mu \mathrm{m} \times 24.99 \mu \mathrm{m})$. Whereas minimum size of conidia was observed in Rajooru (Et23) $(29.15 \mu \mathrm{m} \times 16.66$ $\mu \mathrm{m})$ isolate. These morphological results are similar with the findings of Harlapur et al., (2007) who observed variation in morphological and cultural characters of 16 isolates of E. turcicum. He also studied colony character, colony diameter, mycelial dry weight, spore germination and sporulation.

Similar variation in the isolates of the pathogen from different locations of North Eastern Karnataka were reported by Khedekar (2009) and Rashmi (2015).

Variability among the isolates may be attributed to long term influence of weather conditions of particular location and ability of the pathogen to adapt to the varieties developed in a specific situation.

Highly virulent isolates exhibited higher infection types on host, whereas less virulent isolates were unable to produce more infection as compared to virulent isolates (Harlapur et al., 2007 and Rashmi, 2015). Thus, it clearly indicated the existence of different strains having virulence within E. turcicum.

In the present findings the isolates Gudekote (Et11), Kottur (Et13), Rajooru (Et23), having excellent and good mycelia growth as well as sporulation and these factors are generally considered as virulent factors of the pathogens and have significant relation with the high severity (32.00, 38.00 and $24.00 \%$ respectively) of the disease in these locations during the survey kharif 2016.

\section{Reaction of maize inbred lines against $E$. turcicum isolates}

It is evident that the different inbred lines of maize included in the present study were able to differentiate the virulence of the pathogen associated with geographical origin of the isolates. 
Table.1 Cultural and morphological variations in different isolates of Exserohilum turcicum

\begin{tabular}{|c|c|c|c|c|c|c|c|c|c|c|c|c|}
\hline \multirow[t]{2}{*}{$\begin{array}{l}\text { Sl. } \\
\text { No }\end{array}$} & \multirow[t]{2}{*}{ Location } & \multirow[t]{2}{*}{$\begin{array}{l}\text { Isolate } \\
\text { No. }\end{array}$} & \multirow[t]{2}{*}{ Colony character } & \multirow{2}{*}{$\begin{array}{l}\text { Mean } \\
\text { Colony } \\
\text { diameter } \\
(\mathbf{m m})\end{array}$} & \multirow{2}{*}{$\begin{array}{l}\text { Pigment- } \\
\text { ation }\end{array}$} & \multirow[t]{2}{*}{ Margin } & \multirow[t]{2}{*}{$\begin{array}{l}\text { Margin } \\
\text { colour }\end{array}$} & \multirow[t]{2}{*}{$\begin{array}{l}\text { Spore } \\
\text { colour }\end{array}$} & \multirow[t]{2}{*}{$\begin{array}{l}\text { Sporu- } \\
\text { lation }\end{array}$} & \multirow{2}{*}{$\begin{array}{c}\text { No. } \\
\text { of } \\
\text { septa }\end{array}$} & \multicolumn{2}{|c|}{$\begin{array}{c}\text { Size of conidia } \mu \mathrm{m} \\
(\mathbf{1 0 X})\end{array}$} \\
\hline & & & & & & & & & & & Length & Breadth \\
\hline 1 & $\begin{array}{l}\text { Raddewadgi } \\
\text { (Kalaburagi) }\end{array}$ & Et1 & $\begin{array}{l}\text { Moderate growth, whitish } \\
\text { gray, slightly raised white } \\
\text { cottony growth colony }\end{array}$ & 72 & $\begin{array}{l}\text { Whitish } \\
\text { gray }\end{array}$ & Irregular & Black & Brownish & ++ & $3-8$ & 52.25 & 20.82 \\
\hline 2 & $\begin{array}{l}\text { Farathabad } \\
\text { (Kalaburagi) }\end{array}$ & Et2 & $\begin{array}{l}\text { Poor growth, whitish gray, } \\
\text { slightly raised cottony growth } \\
\text { colony }\end{array}$ & 70 & $\begin{array}{l}\text { Whitish } \\
\text { gray }\end{array}$ & Irregular & Black & $\begin{array}{c}\text { Dark } \\
\text { brownish }\end{array}$ & ++ & $3-7$ & 49.98 & 16.66 \\
\hline 3 & $\begin{array}{c}\text { Udanur } \\
\text { (Kalaburagi) }\end{array}$ & Et3 & $\begin{array}{l}\text { Moderate growth, grayish } \\
\text { black, slightly raised cottony } \\
\text { growth colony }\end{array}$ & 75 & $\begin{array}{l}\text { Grayish } \\
\text { black }\end{array}$ & Irregular & Gray & Brownish & + & $3-8$ & 52.06 & 22.82 \\
\hline 4 & $\begin{array}{l}\text { Hagari } \\
\text { (Ballari) }\end{array}$ & Et4 & $\begin{array}{l}\text { Excellent growth, grayish } \\
\text { black, slightly raised growth } \\
\text { colony }\end{array}$ & 87 & $\begin{array}{l}\text { Grayish } \\
\text { black }\end{array}$ & Regular & Gray & $\begin{array}{c}\text { Dark } \\
\text { brownish }\end{array}$ & ++++ & $3-9$ & 66.64 & 29.15 \\
\hline 5 & $\begin{array}{c}\text { Hanakanaha } \\
\text { lli } \\
\text { (Ballari) }\end{array}$ & Et5 & $\begin{array}{l}\text { Excellent growth, grayish } \\
\text { black, slightly raised cottony } \\
\text { growth colony }\end{array}$ & 86 & $\begin{array}{l}\text { Grayish } \\
\text { black }\end{array}$ & Regular & Black & Brownish & ++ & $3-8$ & 57.27 & 24.99 \\
\hline 6 & $\begin{array}{l}\text { Sidargadda } \\
\text { (Ballari) }\end{array}$ & Et6 & $\begin{array}{l}\text { Good growth, grayish, fluffy } \\
\text { raised growth colony }\end{array}$ & 85 & Grayish & Regular & Gray & Brownish & + & $3-6$ & 54.14 & 20.82 \\
\hline 7 & $\begin{array}{l}\text { Banapur } \\
\text { (Ballari) }\end{array}$ & Et7 & $\begin{array}{l}\text { Excellent growth, grayish } \\
\text { black, slightly raised cottony } \\
\text { growth colony }\end{array}$ & 88 & $\begin{array}{l}\text { Grayish } \\
\text { black }\end{array}$ & Irregular & Black & Brownish & ++ & $3-6$ & 62.47 & 24.99 \\
\hline 8 & $\begin{array}{l}\text { Bevinahalli } \\
\text { (Ballari) }\end{array}$ & Et8 & $\begin{array}{c}\text { Excellent growth, grayish } \\
\text { black, raised cottony growth } \\
\text { colony }\end{array}$ & 87 & $\begin{array}{l}\text { Grayish } \\
\text { black }\end{array}$ & Regular & $\begin{array}{l}\text { Light } \\
\text { gray }\end{array}$ & $\begin{array}{c}\text { Dark } \\
\text { brownish }\end{array}$ & +++ & $3-7$ & 57.12 & 29.15 \\
\hline 9 & $\begin{array}{l}\text { Choornoor } \\
\text { (Ballari) }\end{array}$ & Et9 & $\begin{array}{l}\text { Poor growth, blackish, slightly } \\
\text { raised cottony growth colony }\end{array}$ & 69 & Blackish & Irregular & Black & Brownish & + & $3-9$ & 97.87 & 26.4 \\
\hline 10 & $\begin{array}{l}\text { Sovenahalli } \\
\text { (Ballari) }\end{array}$ & Et10 & $\begin{array}{l}\text { Good growth, Blackish, raised } \\
\text { cottony growth colony }\end{array}$ & 82 & Blackish & Regular & Black & $\begin{array}{l}\text { Dark } \\
\text { brownish }\end{array}$ & ++ & $3-8$ & 66.64 & 24.99 \\
\hline 11 & $\begin{array}{l}\text { Gudekote } \\
\text { (Ballari) }\end{array}$ & Et11 & $\begin{array}{l}\text { Good growth, whitish grey, } \\
\text { fluffy with raised cottony }\end{array}$ & 80 & $\begin{array}{l}\text { Whitish } \\
\text { gray }\end{array}$ & Irregular & Gray & $\begin{array}{c}\text { Dark } \\
\text { brownish }\end{array}$ & ++++ & $3-6$ & 62.47 & 24.99 \\
\hline
\end{tabular}




\begin{tabular}{|c|c|c|c|c|c|c|c|c|c|c|c|c|}
\hline & & & growth colony & & & & & & & & & \\
\hline 12 & $\begin{array}{l}\text { Aedigudda } \\
\text { (Ballari) }\end{array}$ & Et12 & $\begin{array}{l}\text { Excellent growth, grayish } \\
\text { black, fluffy raised cottony } \\
\text { growth colony }\end{array}$ & 90 & $\begin{array}{c}\text { Grayish } \\
\text { black }\end{array}$ & Regular & $\begin{array}{l}\text { Light } \\
\text { gray }\end{array}$ & Brownish & +++ & $3-8$ & 70.80 & 24.99 \\
\hline 13 & $\begin{array}{l}\text { Kottur } \\
\text { (Ballari) }\end{array}$ & Et13 & $\begin{array}{l}\text { Excellent growth, dark } \\
\text { blackish, slightly raised with } \\
\text { center raised colony }\end{array}$ & 88 & $\begin{array}{c}\text { Dark } \\
\text { blackish }\end{array}$ & Irregular & Black & $\begin{array}{c}\text { Dark } \\
\text { brownish }\end{array}$ & ++++ & $3-9$ & 83.7 & 23.4 \\
\hline 14 & $\begin{array}{c}\text { Dibbadahalli } \\
\text { (Ballari) }\end{array}$ & Et14 & $\begin{array}{c}\text { Excellent growth, grayish } \\
\text { black, slightly raised growth } \\
\text { colony }\end{array}$ & 90 & $\begin{array}{l}\text { Grayish } \\
\text { black }\end{array}$ & Regular & Black & $\begin{array}{c}\text { Dark } \\
\text { brownish }\end{array}$ & + & $3-7$ & 97.87 & 29.15 \\
\hline 15 & $\begin{array}{l}\text { Nagati } \\
\text { basapur } \\
\text { (Ballari) }\end{array}$ & Et15 & $\begin{array}{l}\text { Good growth, grayish black, } \\
\text { slightly fluffy raised with } \\
\text { cottony growth colony }\end{array}$ & 82 & $\begin{array}{c}\text { Grayish } \\
\text { black }\end{array}$ & Irregular & Gray & Brownish & ++ & $3-6$ & 41.65 & $24 . .99$ \\
\hline 16 & $\begin{array}{l}\text { Hadagali } \\
\text { (Ballari) }\end{array}$ & Et16 & $\begin{array}{l}\text { Excellent growth, grayish } \\
\text { black, slightly raised cottony } \\
\text { growth colony }\end{array}$ & 88 & $\begin{array}{c}\text { Grayish } \\
\text { black }\end{array}$ & Regular & $\begin{array}{l}\text { Whitis h } \\
\text { gray }\end{array}$ & $\begin{array}{c}\text { Dark } \\
\text { brownish }\end{array}$ & +++ & $3-15$ & 120.78 & 29.15 \\
\hline 17 & $\begin{array}{l}\text { Dasapur } \\
\text { (Ballari) }\end{array}$ & Et17 & $\begin{array}{l}\text { Excellent growth, grayish } \\
\text { black, slightly raised cottony } \\
\text { growth colony }\end{array}$ & 86 & $\begin{array}{c}\text { Grayish } \\
\text { black }\end{array}$ & Irregular & $\begin{array}{l}\text { Whitish } \\
\text { gray }\end{array}$ & Brownish & +++ & $3-5$ & 33.32 & 16.62 \\
\hline 18 & $\begin{array}{l}\text { Hiresindagi } \\
\text { (Koppal) }\end{array}$ & Et18 & $\begin{array}{l}\text { Good growth, grayish black, } \\
\text { fluffy raised cottony growth } \\
\text { colony }\end{array}$ & 84.5 & $\begin{array}{c}\text { Grayish } \\
\text { black }\end{array}$ & Regular & Gray & Brownish & + & $3-7$ & 49.98 & 16.66 \\
\hline 19 & $\begin{array}{l}\text { Hulihyder } \\
\text { (Koppal) }\end{array}$ & Et19 & $\begin{array}{l}\text { Excellent growth,grayish, } \\
\text { raised fluffy growth with } \\
\text { cottony growth colony }\end{array}$ & 90 & Grayish & Regular & Gray & Brownish & + & $3-6$ & 91.63 & 20.82 \\
\hline 20 & $\begin{array}{c}\text { Wadaganahal } \\
\text { (Koppal) }\end{array}$ & Et20 & $\begin{array}{l}\text { Good growth, grayish black, } \\
\text { slightly raised with cottony } \\
\text { growth colony }\end{array}$ & 82 & $\begin{array}{c}\text { Grayish } \\
\text { black }\end{array}$ & Irregular & Gray & Brownish & + & $3-8$ & 97.18 & 29.15 \\
\hline 21 & $\begin{array}{l}\text { Byadihal } \\
\text { (Koppal) }\end{array}$ & Et21 & $\begin{array}{l}\text { Excellent growth, grayish } \\
\text { black, raised cottony growth } \\
\text { colony }\end{array}$ & 85 & $\begin{array}{c}\text { Grayish } \\
\text { black }\end{array}$ & Regular & Black & Brownish & ++ & $3-5$ & 97.87 & 33.32 \\
\hline
\end{tabular}




\begin{tabular}{|c|c|c|c|c|c|c|c|c|c|c|c|c|}
\hline 22 & $\begin{array}{l}\text { Kushtagi } \\
\text { (Koppal) }\end{array}$ & Et22 & $\begin{array}{c}\text { Excellent growth, grayish } \\
\text { black, slightly raised growth } \\
\text { colony }\end{array}$ & 88 & $\begin{array}{l}\text { Grayish } \\
\text { black }\end{array}$ & Regular & Gray & Brownish & +++ & $3-4$ & 49.98 & 24.99 \\
\hline 23 & $\begin{array}{l}\text { Rajooru } \\
\text { (Koppal) }\end{array}$ & Et23 & $\begin{array}{l}\text { Good growth, grayish black, } \\
\text { raised cottony growth colony }\end{array}$ & 85 & $\begin{array}{c}\text { Grayish } \\
\text { black }\end{array}$ & Irregular & Black & $\begin{array}{c}\text { Dark } \\
\text { brownish }\end{array}$ & ++++ & $3-4$ & 29.15 & 16.66 \\
\hline 24 & $\begin{array}{l}\text { Mataladinni } \\
\text { (Koppal) }\end{array}$ & Et24 & $\begin{array}{l}\text { Excellent growth, grayish, } \\
\text { fluffy raised cottony growth } \\
\text { colony }\end{array}$ & 88 & Grayish & Regular & $\begin{array}{l}\text { Light } \\
\text { gray }\end{array}$ & $\begin{array}{c}\text { Dark } \\
\text { brownish }\end{array}$ & ++++ & $3-9$ & 72.88 & 24.99 \\
\hline 25 & $\begin{array}{c}\text { Bandi } \\
\text { (Koppal) }\end{array}$ & Et25 & $\begin{array}{l}\text { Excellent growth, blackish } \\
\text { flattened cottony growth } \\
\text { colony }\end{array}$ & 87 & Blackish & Regular & Black & Brownish & + & $3-4$ & 70.8 & 16.66 \\
\hline 26 & $\begin{array}{l}\text { Nittali } \\
\text { (Koppal) }\end{array}$ & Et26 & $\begin{array}{l}\text { Good growth, blackish raised } \\
\text { cottony growth colony }\end{array}$ & 82 & Blackish & Irregular & Black & $\begin{array}{c}\text { Dark } \\
\text { brownish }\end{array}$ & ++++ & $3-6$ & 33.32 & 16.66 \\
\hline 27 & $\begin{array}{l}\text { Tuppargadde } \\
\text { (Koppal) }\end{array}$ & Et27 & $\begin{array}{l}\text { Excellent growth, dark } \\
\text { grayish, slightly raised cottony } \\
\text { growth colony }\end{array}$ & 89 & $\begin{array}{l}\text { Dark } \\
\text { grayish }\end{array}$ & Irregular & Gray & $\begin{array}{c}\text { Dark } \\
\text { Brownish }\end{array}$ & ++++ & $3-10$ & 83.3 & 20.82 \\
\hline 28 & $\begin{array}{l}\text { Kanakagiri } \\
\text { (Koppal) }\end{array}$ & Et28 & $\begin{array}{l}\text { Excellent growth, grayish } \\
\text { black, raised fluffy growth } \\
\text { with cottony growth colony }\end{array}$ & 90 & $\begin{array}{l}\text { Grayish } \\
\text { black }\end{array}$ & Regular & Black & $\begin{array}{c}\text { Dark } \\
\text { brownish }\end{array}$ & +++ & $3-15$ & 116.62 & 24.99 \\
\hline 29 & $\begin{array}{c}\text { Bheemarayan } \\
\text { agudi } \\
\text { (Yadgir) }\end{array}$ & Et29 & $\begin{array}{l}\text { Excellent growth, grayish } \\
\text { black, raised cottony growth } \\
\text { colony }\end{array}$ & 87 & $\begin{array}{l}\text { Grayish } \\
\text { black }\end{array}$ & Regular & Black & Brownish & ++ & $3-6$ & 99.96 & 29.15 \\
\hline 30 & $\begin{array}{l}\text { Googi } \\
\text { (Yadgir) }\end{array}$ & Et30 & $\begin{array}{l}\text { Moderate growth, blackish } \\
\text { flattened slightly raised } \\
\text { growth colony }\end{array}$ & 78 & Blackish & Irregular & $\begin{array}{l}\text { Whitish } \\
\text { gray }\end{array}$ & $\begin{array}{c}\text { Dark } \\
\text { brownish }\end{array}$ & + & $3-6$ & 70.80 & 16.66 \\
\hline 31 & $\begin{array}{l}\text { Manvi } \\
\text { (Raichur) }\end{array}$ & Et31 & $\begin{array}{c}\text { Moderate growth, grayish } \\
\text { black flattened slightly raised } \\
\text { growth colony }\end{array}$ & 80 & $\begin{array}{l}\text { Grayish } \\
\text { black }\end{array}$ & Irregular & Black & Brownish & + & $3-7$ & 74.97 & 24.99 \\
\hline 32 & $\begin{array}{l}\text { Raichur } \\
\text { (Raichur) }\end{array}$ & Et32 & $\begin{array}{l}\text { Excellent growth,blackish, } \\
\text { slightly raised growth colony }\end{array}$ & 90 & Blackish & Regular & Black & Brownish & ++ & $3-7$ & 108.29 & 24.99 \\
\hline
\end{tabular}


Table.2 Reaction of maize inbred lines against different isolates of E. turcicum

\begin{tabular}{|c|c|c|c|c|c|c|c|c|}
\hline \multirow{2}{*}{$\begin{array}{l}\text { Sl. } \\
\text { No. }\end{array}$} & \multirow[t]{2}{*}{ Isolates } & \multicolumn{6}{|c|}{ Inbred lines / Average lesion size $\left(\mathrm{cm}^{2}\right)$} & \multirow{2}{*}{$\begin{array}{c}\text { Mean } \\
\text { lesion } \\
\text { size } \\
\left(\mathrm{cm}^{2}\right)\end{array}$} \\
\hline & & CI-4 & HS-2 & $\begin{array}{l}\text { CM- } \\
202\end{array}$ & $\begin{array}{c}\text { MI- } \\
39\end{array}$ & 9208B & 9202B & \\
\hline 1 & Anantpur (AP) & 0.72 & 0.96 & 2.48 & 0.76 & 0.22 & 0.23 & 0.89 \\
\hline 2 & Farathabad & 0.05 & 0.55 & 1.00 & 3.69 & 0.47 & 0.85 & 1.10 \\
\hline 3 & Udanur & 0.12 & 0.56 & 0.98 & 0.35 & 1.28 & 0.73 & 0.67 \\
\hline 4 & Gauribidanur & 0.12 & 0.25 & 1.27 & 1.85 & 0.02 & 0.22 & 0.62 \\
\hline 5 & Raddewadgi & 0.48 & 0.08 & 1.50 & 0.49 & 0.11 & 0.12 & 0.46 \\
\hline 6 & Gudekote & 0.05 & 0.14 & 0.79 & 1.20 & 0.24 & 0.40 & 0.47 \\
\hline 7 & Hagari & 0.02 & 0.30 & 1.84 & 1.90 & 0.30 & 1.62 & 0.99 \\
\hline 8 & Kudligi & 0.05 & 0.05 & 1.50 & 0.95 & 0.25 & 0.03 & 0.47 \\
\hline 9 & Kushtagi & 0.10 & 0.01 & 0.16 & 0.77 & 0.28 & 0.14 & 0.24 \\
\hline 10 & Aedigudda & 0.70 & 0.07 & 1.85 & 1.23 & 0.11 & 0.01 & 0.66 \\
\hline 11 & Raichur & 0.56 & 0.15 & 1.30 & 1.05 & 0.75 & 0.71 & 0.75 \\
\hline 12 & Bheemarayanagudi & 0.72 & 0.77 & 1.20 & 1.50 & 1.05 & 0.78 & 1.00 \\
\hline 13 & Bandi & 0.33 & 0.25 & 1.07 & 0.86 & 0.18 & 0.43 & 0.52 \\
\hline 14 & Rajoor & 0.04 & 0.10 & 0.75 & 1.53 & 0.15 & 0.47 & 0.50 \\
\hline 15 & Kottur & 0.13 & 0.10 & 0.65 & 0.35 & 0.05 & 0.22 & 0.25 \\
\hline 16 & Mataladinni & 0.28 & 0.14 & 1.15 & 3.15 & 0.36 & 0.93 & 1.00 \\
\hline 17 & Dharwad & 0.68 & 0.11 & 2.10 & 1.09 & 0.40 & 0.07 & 0.74 \\
\hline 18 & Kanakagiri & 0.10 & 0.37 & 1.33 & 1.20 & 0.15 & 0.50 & 0.61 \\
\hline 19 & Hanumanmatti & 0.02 & 0.11 & 1.10 & 0.64 & 0.01 & 0.33 & 0.36 \\
\hline 20 & Mandya & 0.40 & 0.13 & 2.15 & 1.36 & 0.22 & 0.28 & 0.75 \\
\hline & Mean & 0.28 & 0.26 & 1.31 & 1.29 & 0.33 & 0.45 & 0.65 \\
\hline
\end{tabular}


Fig.1 Cultural variability of different isolates of Exserohilum turcicum on PDA

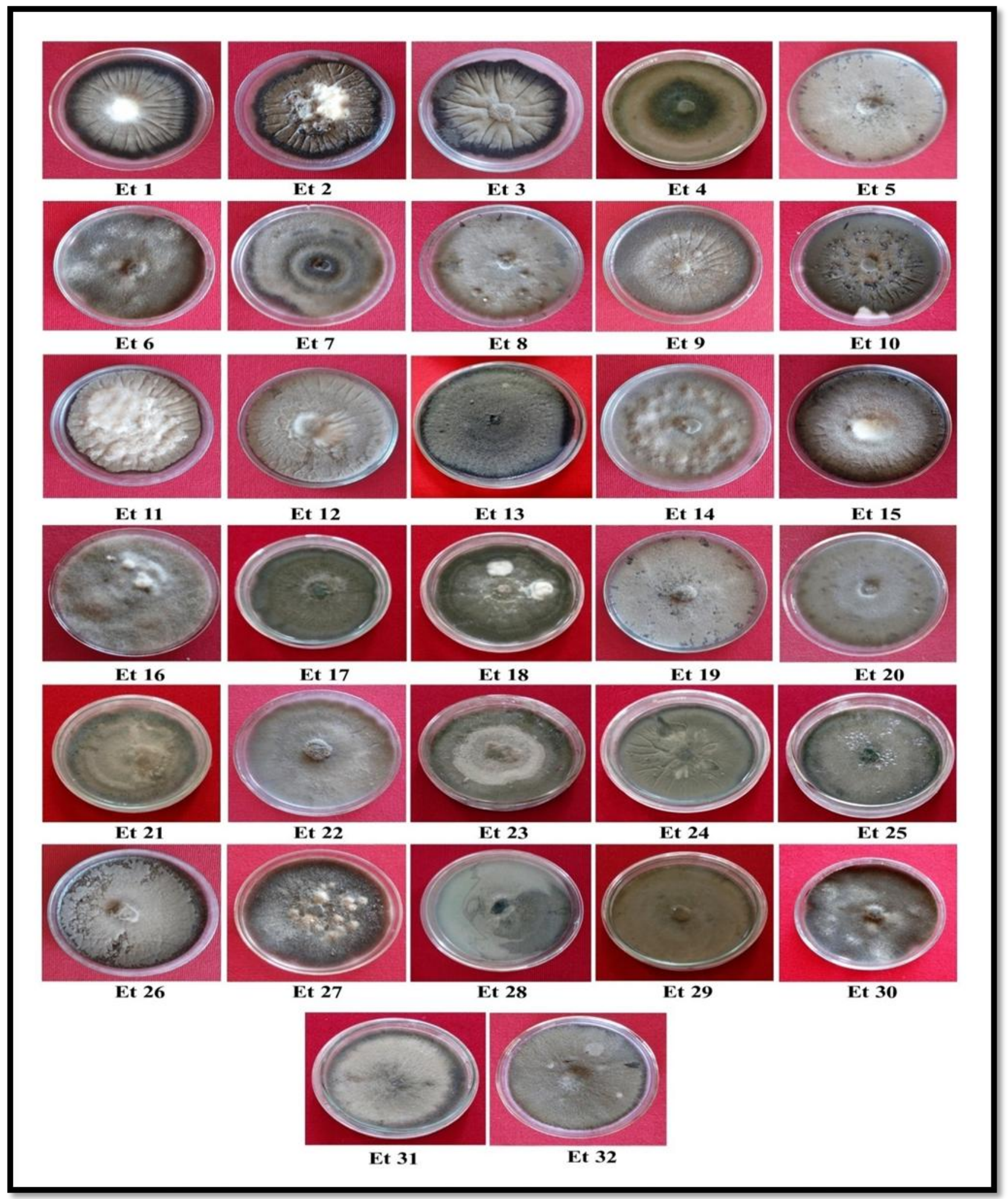


The results showed that irrespective of the isolates in susceptible inbred lines CM-202 and MI-39 exhibited significantly more mean lesion size of $1.31 \mathrm{~cm}^{2}$ and $1.29 \mathrm{~cm}^{2}$, respectively. Similarly, smaller mean lesion size $0.26 \mathrm{~cm}^{2}$ was recorded in resistant inbred line HS-2 irrespective of the isolates. Across the maize inbred lines E. turcicum isolates from Farathabad (Kalaburagi), Bheemarayanagudi (Yadgir) and Mataladinni (Koppal) produced higher mean lesion size of $1.10,1.00$ and 1.00 $\mathrm{cm}^{2}$, respectively whereas small lesion size was noticed in Kushtagi $\left(0.24 \mathrm{~cm}^{2}\right)$ and Kottur $(0.25$ $\mathrm{cm}^{2}$ ) isolates (Table 2).

On susceptible inbred line CM-202, some of the isolates such as Anantpur, Hagari, Aedigudda, Dharwad and Mandya produced maximum lesion size and could be considered as most virulent isolates, But the isolates from Farathabad and Mataladinni recorded maximum lesion size on MI-39 inbred line and these isolates behaved differently on CM-202.

The results indicated that, there were three virulence patterns exhibited on six maize inbred lines after inoculating with 20 isolates of $E$. turcicum. The isolates from Farathabad and Mataladinni were highly pathogenic on MI-39 which was having a disease reaction as 5 while HS-2 showed least disease reaction against almost all isolates (1-2). CM-202 and MI-39 inbred lines showed moderately resistance to highly susceptible reaction to majority of the isolates (3 to 5 reaction). The inbred lines viz., NEI-9202B, NEI-9208B showed highly resistant to resistant reaction (1) for most of the isolates. Whereas CI-4 and HS-2 showed resistance to moderately resistance to moderately resistance reaction to most of the isolates.

Based on the disease reaction of these maize inbred lines, the isolates could be grouped into three virulent types viz., the isolates has reaction 2.50 as most virulent, reaction between 1.5-2.00 as moderately virulent and reaction upto 1.5 as less virulent type.

Therefore, the reason for lack of resistance in some of the commercial cultivars of maize may be attributed to the prevalence of virulent isolates of the pathogen E. turcicum similar observations were made by Pandurangegowda et al.,(1993). The information generated through present study is useful in resistance breeding programme and deploy the resistant gene for management of TLB effectively.

The results of the present findings were supported by the Daniel and Narong (2006) observed variation in pathogenic variability of 70 isolates of E. turcicum, among that 20 representative were selected and evaluated for pathogenicity on 11 seedlings of maize varieties. They also studied lesion size which varied from 0.69 to $2.91 \mathrm{~cm}^{2}$. Present findings are also in conformity with earlier findings (Nelson et al., 1970 and Muiru et al., 2008).

Who opinion that, reason for lack of substantial durable resistance in the cultivated hybrids might attributed to the presence of variability in the population. In order to develop the disease resistant and high yielding cultivars, it is imperative to analyse and understand the variability in the pathogen. The present findings indicated that the isolates from Anantpur (AP), Farathabad, Hagari, Raichur, Bheemarayanagudi, Mataladinni and Dharwad were quite distinct and found highly virulent compared to other isolates tested on the some inbred lines.

\section{References}

Anonymous, 2010, Project Director Review 2013-14: All India Co-ordinated Maize Research Project, Directorate of Maize Research, New Delhi, pp. 2.

Anonymous, 2016, Project Director Review 2015-16: All India Co-ordinated Maize Research Project, Directorate of Maize Research, New Delhi, pp. 8.

Daniel, A. and Narong, S., 2006, Morphological, cultural and pathogenicity variation of Exserohilum turcicum isolates in maize (Zea mays L.). Kasetsart J. National Sci., 40: 341-352. 
Dowswell, C. R., Paliwal, R. L. and Cantrell, R. P., 1996, Maize in the third world, pp. 1-37. West view press.

Galaninat, F., 1976, Cereal crops. Macmillan publishers company, London.

Harlapur, S. I., 2005, Epidemiology and management of turcicum leaf blight of maize caused by Exserohilum turcicum (Pass) Leonard and Suggs., Ph. D. Thesis, Univ. Agril. Sci., Dharwad, Karnataka, India. pp.150.

Harlapur, S. I., Kulkarni, M. S., Yeshoda, H. and Srikant, K., 2007, Variability in Exserohilum turcicum causal agent of turcicum leaf blight of maize. Karnataka J. Agric. Sci., 20(3): 665-666.

Hulagappa, 2012, Studies on maydis leaf blight of maize caused by Drechslera maydis (Nisikado) Subram and Jain. M.Sc. (Agri.) Thesis, Univ. Agric. Sci., Dharwad, Karnataka (India).

Khedekar, S. A., 2009, Investigations on the variability and management of turcicum leaf blight in maize caused by Exserohilum turcicum (pass.) Leonard and suggs. M.Sc.(Agri). Thesis, Univ. Agric. Sci., Dharwad, Karnataka (India).

Muiru, W. M., Mutitu, E. W. and Kimenju, J. W., 2008, Distribution of turcicum leaf blight of maize in Kenya and cultural variability of its causal agents, Exserohilum turcicum. J. Trop. Microbiol. and Biochem., 4(1): 32-39.

Nataraj, K., 2014, Studies on toxin production, variability and management of turcicum leaf blight of maize caused by Exserohilum turcicum (Pass.) Leonard and Suggs. M. Sc. (Agri.) Thesis, Univ. Agric. Sci., Raichur, Karnataka (India).
Nelson, R. R., Mackenzie D. R. and Schiefele, G. L., 1970, Interaction of genes for phytopathogenicity and virulence in Trichometaspaeria turcica with different numbers of gene for vertical resistance in Zea mays. Phytopathol. 60: 12501254.

Pandurangegowda, K. T., Shetty, H. S., Gowda, B. J., Prakash, H. S. and Sangamlal, 1993, Comparison of two methods for assessment of yield losses due to turcicum leaf blight of maize. Indian Phytopath., 45: 316-320.

Payak, M. M, Sharma, R. C. and Lilaramani, J., 1973, How to control maize diseases. Indian Farming., 23: 20-23.

Payak, M. M. and Sharma, R. C., 1985, Maize diseases and approaches to their management. Trop. pest management, 31: 302-310.

Perkins, J. M. and Pederson, W. L., 1987, Disease treatment and yield loss associated with northern leaf blight of corn. Pl. Dis., 71: 940-943.

Purslgove, G. M., 1972, Monocotyledonous crops. Third edition. Chapmam and Hall, London.

Rashmi, R., 2015, Epidemiology and disease resistance in maize against turcicum leaf blight (Exserohilum turcicum). M.Sc. (Agri.) Thesis, Univ. Agric. Sci., Raichur, Karnataka, 5-40.

Raymundo, A. D. and Hooker, A. C., 1981, Measuring relationship between northern leaf blight of maize and yield losses. $P l$. Dis. Bull., 65: 325-327.

Smith, D. R., 1999, Global disease assessment of corn. In: Proc. fifty-fourth Annual Corn and Sorghum Res. Conf., December 9-10, Chicago, 54pp.

\section{How to cite this article:}

Geeta, D.S. Aswathanarayana, M.K. Naik, Mallikarjun Kenganal and Prakash H. Kuchanur. 2019. Cultural, Morphological and Pathogenic Variability of Exserohilum turcicum causing Turcicum Leaf Blight in Maize. Int.J.Curr.Microbiol.App.Sci. 8(11): 302-313. doi: https://doi.org/10.20546/ijcmas.2019.811.038 